Journal homepage: www.aesacademy.org

\title{
Phytochemical screening and in vitro antibacterial activity of Moringa oleifera (Lam.) leaf extract
}

\section{Satinder Pal Kaur Malhotra* (iD and Tapan Kumar Mandal}

Faculty of Science \& Technology, ICFAI University Dehradun, Rajawala Road, Selaqui, Dehradun-248197 (Uttarakhand), INDIA ${ }^{*}$ Corresponding author's E-mail: malhotrasatinder@gmail.com

\section{ARTICLE HISTORY}

Received: 05 November 2018

Revised received: 18 November 2018

Accepted: 22 November 2018

\section{GRAPHICAL ABSTRACT}

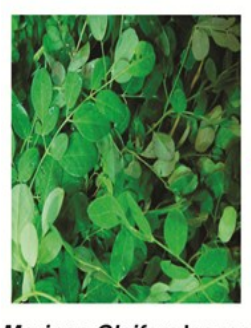

Moringa Oleifera leaves

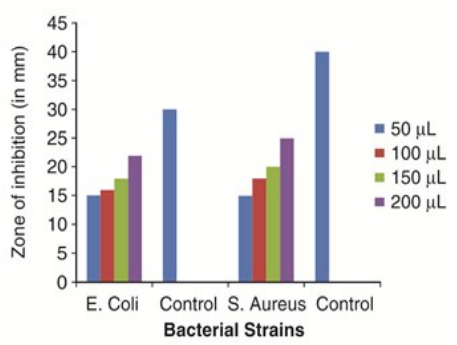

Antibacterial Activity of Ethanolic extract of Moringa Oleifera leaf

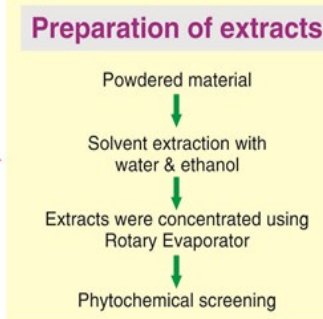

Moringa Oleifera leaf powder
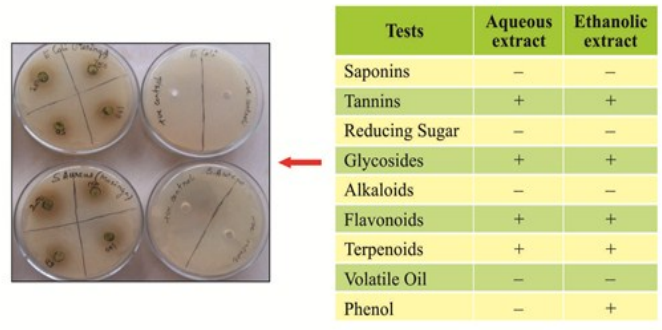

Phytochemical Screening of Moringa Oleifera leaf extract

\section{Keywords}

Agar well diffusion method

Antibacterial activity

Moringa oleifera Lam.

Phytochemical Screening

\section{ABSTRACT}

The aim of the study was to investigate the phytochemical constituents and antibacterial activity of ethanolic extract of Moringa oleifera Lam. belonging to family Moringaceae. Distilled water and ethanol was used to extract the bioactive compounds from the leaves of M. oleifera to detect the phytochemical constituents and to screen its antibacterial activity. The phytochemical constituents were screened by qualitative analysis method. The phytochemical screening indicated the presence of tannins, flavonoids, glycosides, terpenoids, phenols, etc., in leaf extract of M. oleifera. The antibacterial activity of ethanolic leaf extract of M. oleifera was examined against gram positive bacteria (Staphylococcus aureus) and gram negative bacteria (Escherichia coli). Antibacterial assay were done with ethanolic extract of M. oleifera in volumes 50, 100, 150 and $200 \mu \mathrm{L} /$ well, using agar well diffusion method. The study showed that ethanolic extract of $M$. oleifera showed potent antibacterial activity against $S$. Aureus and $E$. coli.

(C)2018 Agriculture and Environmental Science Academy

Citation of this article: Malhotra, S.P.K. and Mandal, T.K. (2018). Phytochemical screening and in vitro antibacterial activity of Moringa oleifera Lam., leaf extract. Archives of Agriculture and Environmental Science, 3(4): 367-372. https:// dx.doi.org/10.26832/24566632.2018.030406 


\section{INTRODUCTION}

Moringa (Moringa oleifera Lam.) is a type of local medicinal Indian herb belonging to the family of Moringaceae. The tree is often referred to as a "wonder-tree" for its multipurpose usability and also known as "Drumstick-tree", "Horseradish-tree" and "Benoil tree". M. oleifera is found in many tropical and sub-tropical regions (Berkovich et al., 2013; Rockwood et al., 2013; Daba, 2016). Moringa can be grown in the even the harshest and driest of soils, where scarcely anything else will grow. Moringa is nicknamed "never die" because of its staggering capacity to endure harsh climate and even dry season. Traditionally, besides being a daily used vegetable among people of these regions, Moringa is also widely known and used for its health benefits. M. oleifera is considered as "miracle tree" due to its amazing healing abilities for various ailments and even some chronic diseases because all its parts are used, especially for their pharmacological and nutritional properties (Rockwood et al., 2013).

Moringa is wealthy in nutrition attributable to the presence of a spread of essential phytochemicals gift in its leaves, pods and seeds. In fact, Moringa provides 7 times more vitamin $C$ than oranges, 10 times more vitamin A than carrots, 17 times more calcium than milk, 9 times more protein than yoghurt, 15 more potassium than bananas and 25 times more iron than spinach (Rockwood et al., 2013). The leaves of Moringa oleifera are rich in minerals like calcium, potassium, zinc, magnesium, iron and copper (Kasolo et al., 2010).Vitamins like beta-carotene of vitamin $A$, vitamin B such as folic acid, pyridoxine and nicotinic acid, vitamin C, D and E also present in M. oleifera (Vinoth et al., 2012; Mbikay, 2012). Phytochemicals such as tannins, sterols, terpenoids, flavonoids, saponins, anthraquinones, alkaloids and reducing sugar present along with anti-cancerous agents like glucosinolates, isothiocyanates, glycoside compounds and glycerol-1-9-octadecanoate (Berkovich et al., 2013). M. oleifera leaves show around 25.5-31.03 $\mathrm{mg}$ of zinc per $\mathrm{kg}$, which is the daily requirement of zinc in the diet (Barminas et al., 1998).

Various parts of the plant such as the leaves, roots, seed, bark, fruit, flowers and immature pods act as cardiac and circulatory stimulants, possess anti-tumour, antipyretic, anti-epileptic, antiinflammatory, anti-ulcer ( $\mathrm{Pal}$ et al., 1995). Other important medicinal properties of the plant include anti-spasmodic (Cáceres et al., 1992), diuretic (Morton, 1991), anti-hypertensive (Dahot, 1988), cholesterol lowering (Mehta et al., 2003), antioxidant, anti-diabetic, hepatoprotective (Ruckmani et al.,1998), anti -bacterial and anti-fungal activities (Nikkon et al., 2003). The aqueous extracts of roots and barks were found to be effective in preventing implantation, aqueous extracts of fruits have shown significant anti-inflammatory activity, methanolic extracts of leaves have shown anti-ulcer activity and ethanolic extracts of seeds exhibited anti-tumour activity (Patel Rameshwar et al., 2010). The leaves of Moringa contains bioactive compounds called $\beta$-sitosterol which are highly involved in the stabilization of the cholesterol level in the serum of the high fat diet fed rats (Ghasi et al., 2000). Moringa leaves are highly rich in $\beta$-carotene and leutin which supplies the vitamin $A$ that is highly responsible to prevent the night blindness and also the eye problems in the children. The juices of the Moringa leaves were also involved in the treatment of the conjunctivitis. $M$. oleifera can be used as an anti-cancer agent as it is natural, reliable and safe, at established concentrations. Studies have shown that Moringa can be used as an anti-neoproliferative agent, thereby, inhibiting the growth of cancer cells. Soluble and solvent extracts of leaves have been proven effective as anticancer agents due to its ability to induce reactive oxygen species in the cancer cells which lead to apoptosis. This is further proved by the up regulation of caspase 3 and caspase 9, which are part of the apoptotic pathway (Liou and Storz, 2010; Jung, 2014; Leelawat and Leelawat, 2014).

Moreover, the ROS production by Moringa is specific and targets only cancer cells, making it an ideal anticancer agent. The present study was undertaken to identify phytochemical constituents present in the leaves of M. oleifera and to explore its antibacterial activity.

\section{MATERIALS AND METHODS}

\section{Collection of plant materials}

\section{Plant collection}

Plants leaves were collected from Visakhapatnam, A.P, India. Plant leaves were initially dried in an air conditioned, dehumidified room, then further dried in an oven at ca. $40^{\circ} \mathrm{C}$ for a total of seven days, and then finally ground to a fine powder.

\section{Chemicals used}

Ethanol and distilled water were used in the preparation of extracts. Mueller-Hinton agar, Nutrient broth, disposable sterile petri dishes, cotton swabs, sterile saline, test tubes was purchased from HiMedia Laboratories Pvt. Ltd., Mumbai. Ampicillin was used to check susceptibility and resistance pattern of the bacterial strains. The antibiotic was obtained from local pharmacy store and working solution having $10 \mathrm{mg} / \mathrm{ml}$ concentration of the antibiotic was used for the study.

\section{Bacterial strains}

Bacterial cultures of Gram positive bacteria Staphylococcus aureus (ATCC25923) and Gram negative bacteria Escherichia coli (ATCC25922), were obtained from Microbial Type Culture Collection Center (MTCC), Chandigarh, India. Bacteria were grown in nutrient broth and maintained on nutrient agar slants at $4^{\circ} \mathrm{C}$. They were cultured on nutrient broth (Himedia) at $37^{\circ} \mathrm{C}$ for $24 \mathrm{~h}$.

\section{Preparation of M. oleifera leaf extracts}

\section{Aqueous M. oleifera leaf extract}

Immerse $30 \mathrm{~g}$ of Moringa Oleifera leaf powder in $300 \mathrm{ml}$ of boiled de-ionized water $\left(\mathrm{DI}-\mathrm{H}_{2} \mathrm{O}\right)$ under magnetic stirrer for about $1 \mathrm{~h} 45$ at $50^{\circ} \mathrm{C}$. The mixture was cooled to room tempera- 
ture and filtered through nylon mesh, followed by Whatmann Filter paper no.1. The filtered M. olefeira leaf extract was stored in refrigerator at $4^{\circ} \mathrm{C}$ for further studies.

\section{Ethanolic M. oleifera leaf extract}

Immerse $50 \mathrm{~g}$ of M. oleifera leaf powder in $100 \mathrm{ml}$ of $100 \%$ ethanol for overnight. The ethanol fraction was separated using sterile muslin cloth and filter through sterile Whatmann filter paper no. 01 . The aqueous and ethanolic extract of M. oleifera leaves was protected from light by aluminum foil and stored in refrigerator until used.

\section{Sterility test of the plant extracts}

The aqueous and ethanolic extracts were tested for growth or contamination. This was carried out by inoculating $1 \mathrm{ml}$ each of them on nutrient agar and incubated at $37^{\circ} \mathrm{C}$ for 24 hours. The plates were observed for growth. No growth in the extracts after incubation indicates that the extracts were sterile. The extracts were then accessed for antimicrobial activity.

\section{Phytochemical screening}

The different qualitative phytochemical tests were carried out as per the standard tests for the phyto-constituents such as alkaloids, phenols, flavonoids, tannins, saponins, terpenoids, glycosides, reducing sugars, fats and oils, etc., present in the leaf extracts. The positive tests were noted as present $(+)$ and absent (-).

\section{Saponins}

Saponins were detected using the froth test. $1 \mathrm{~g}$ of the sample was weighed into a conical flask in which $10 \mathrm{ml}$ of sterile distilled water was added and boiled for 5 minutes. The mixture was filtered and $2.5 \mathrm{ml}$ of the filtrate was added to $10 \mathrm{ml}$ of sterile distilled water in a test tube. The test tube was stoppered and shaken vigorously for about 30 seconds. It was then allowed to stand for half an hour. Honeycomb froth indicated the presence of saponins.

\section{Tannins}

To a portion of the extract diluted with water, 3-4 drops of $10 \%$ ferric chloride solution is added. A blue colour is observed for gallic tannins and green colour indicates for catecholic tannins.

\section{Reducing sugars}

To $0.5 \mathrm{ml}$ of plant extracts, $1 \mathrm{ml}$ of water and 5-8 drops of Fehling's solution was added and heated over water bath. Brick red precipitate indicates the presence of reducing sugars.

\section{Glycosides}

$25 \mathrm{ml}$ of dilute sulphuric acid was added to $5 \mathrm{ml}$ extract in a test tube and boiled for 15 minutes, cooled and neutralized with $10 \% \mathrm{NaOH}$, then $5 \mathrm{ml}$ of Fehling's solution added. Glycosides are indicated by a brick red precipitate.

\section{Alkaloids}

$2 \mathrm{ml}$ of extract was measured in a test tube to which picric acid solution was added. An orange coloration indicated the presence of alkaloids.

\section{Flavonoids}

$4 \mathrm{ml}$ of extract solution was treated with $1.5 \mathrm{ml}$ of $50 \%$ methanol solution. The solution was warmed and metal magnesium was added. To this solution, 5-6 drops of concentrated hydrochloric acid was added and red color was observed for flavonoids and orange colour for flavones.

\section{Terpenoids}

Four milligrams of extract was treated with $0.5 \mathrm{ml}$ of acetic anhydride and $0.5 \mathrm{ml}$ of chloroform. Then concentrated solution of sulphuric acid was added slowly and red violet colour was observed for terpenoids.

Volatile oil

$2 \mathrm{ml}$ of extract was shaken with $0.1 \mathrm{ml}$ dilute $\mathrm{NaOH}$ and a small quantity of dilute $\mathrm{HCl}$. A white precipitate is formed if volatile oils are present.

\section{Phenols}

To $2 \mathrm{ml}$ of extract, a few drops of ferric chloride solution was added. The appearance of a greenish yellow colour, confirms the presence of phenol.

\section{Standardization of inoculum media}

The inocula were prepared from the stock cultures, which were maintained on nutrient agar slant at $4^{\circ} \mathrm{C}$ and subcultured into nutrient broth using a sterilized wire loop. Cultures were then adjusted to a concentration of $10^{8} \mathrm{CFU} / \mathrm{mL}$ by making a suspension in $0.85 \%$ saline solution match the $0.5 \mathrm{McF}$ arland turbidity standards (Hindler and Jorgensen, 1995). Active cultures for experiments were prepared by transferring a loop full of cells from the stock cultures to test tubes of nutrient broth for bacteria that were incubated at $24 \mathrm{hrs}$ at $37^{\circ} \mathrm{C}$.

\section{Agar well diffusion method}

The antibacterial activity of ethanolic leaf extract of M. oleifera (1.0 $\mathrm{g} / \mathrm{ml}$ ) against each strain was studied by agar well diffusion method using 50,100,150 and $200 \mu \mathrm{L} /$ well. The Muller Hinton agar plates was prepared and kept for sterilization. After sterilization the media was poured in to sterile petriplates and were allowed to solidify for thirty minutes. After the medium was solidified, it was inoculated with 18 hours old cultures $(100 \mu l)$ of the given test organisms microorganisms by spreading the bacterial inoculums on the over the Muller-Hinton agar medium using sterile cotton swab horizontally and vertically in order to get a uniform microbial growth. Wells of $6 \mathrm{~mm}$. were punched in the agar and filled with plant extracts. The control plates were made by using Ampicillin $(10 \mathrm{mg} / \mathrm{ml})$ as positive control and ethanol as a negative control to determine the sensitivity of bacterial strains. The plates were incubated at $37^{\circ} \mathrm{C}$ for $18-24$ hours. Antimicrobial activity was evaluated by measuring the zones of inhibition against the tested bacteria. Each assay was carried out in triplicate. 


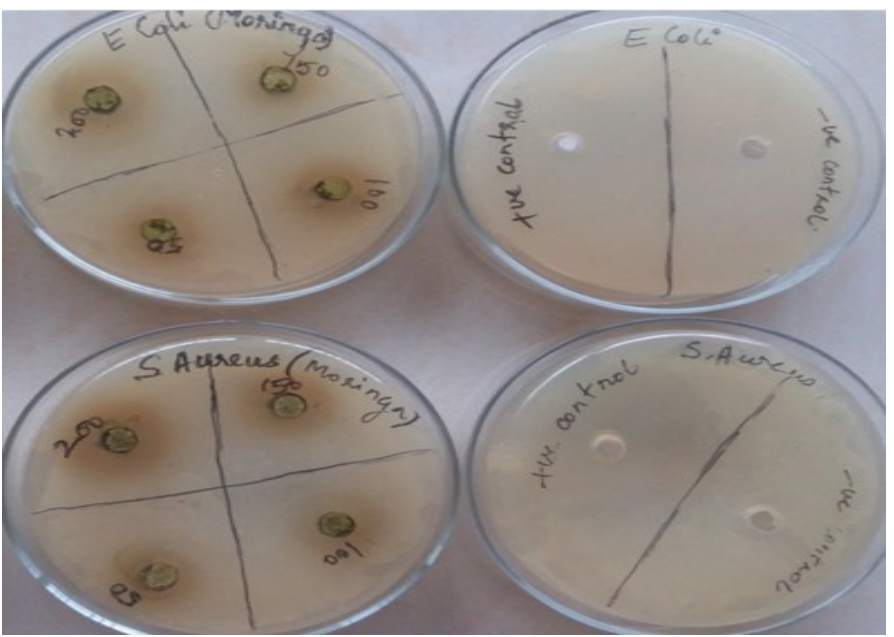

Figure 1. Antibacterial disc diffusion assay plates.

\section{RESULTS AND DISCUSSION}

The qualitative phytochemical analysis of $M$. oleifera leaf extracts was done to test for presence of various phytochemicals. The results of the phytochemical analysis of M. oleifera leaf extracts using water and ethanol are shown in Table 1 . The phytochemical screening indicated the presence of tannins, flavonoids, glycosides, terpenoids, phenols, etc., in leaf extracts of Moringa oleifera that are responsible for its antibacterial activity. The antibacterial activity of ethanolic extract was investigated using agar well diffusion method, against grampositive species (S. aureus) and gram-negative strain (E. coli). The results of antibacterial activity of ethanolic leaf extract of $M$. oleifera are shown in Figure 2 and Table 2. The results show that ethanolic extract of Moringa oleifera had activity against both the test bacteria. The maximum zone of inhibition against $S$. aureus was $25 \mathrm{~mm}$ and E. coli was $22 \mathrm{~mm}$.

The antibacterial activity of the ethanolic extract was greater against gram-positive species ( $S$. aureus) than against gram-

Table1. Phytochemical Screening of Moringa oleifera Lam Leaf extracts.

\begin{tabular}{lcc}
\hline Tests & Aqueous extract & Ethanolic extract \\
\hline Saponins & - & - \\
Tannins & + & + \\
Reducing Sugar & - & - \\
Glycosides & + & + \\
Alkaloids & - & - \\
Flavonoids & + & + \\
Terpenoids & + & + \\
Volatile Oil & - & - \\
Phenol & - & + \\
\hline
\end{tabular}

Table 2. Antimicrobial activity of ethanolic leaf extract of Moringa oleifera against S. Aureus and E.Coli.

\begin{tabular}{|c|c|c|c|c|c|}
\hline \multirow[b]{2}{*}{$\begin{array}{l}\text { Bacterial } \\
\text { strains }\end{array}$} & \multicolumn{5}{|c|}{ Zone of inhibition (mm) } \\
\hline & Ampicillin & $\begin{array}{c}50 \\
\mu \mathrm{L} / \\
\text { Well }\end{array}$ & $\begin{array}{c}100 \\
\mu \mathrm{L} / \\
\text { Well }\end{array}$ & $\begin{array}{c}150 \\
\mu \mathrm{L} / \\
\text { Well }\end{array}$ & $\begin{array}{c}200 \\
\mu \mathrm{L} / \\
\text { Well }\end{array}$ \\
\hline S. aureus & 40 & 15 & 18 & 20 & 25 \\
\hline E. coli & 30 & 15 & 16 & 18 & 22 \\
\hline
\end{tabular}

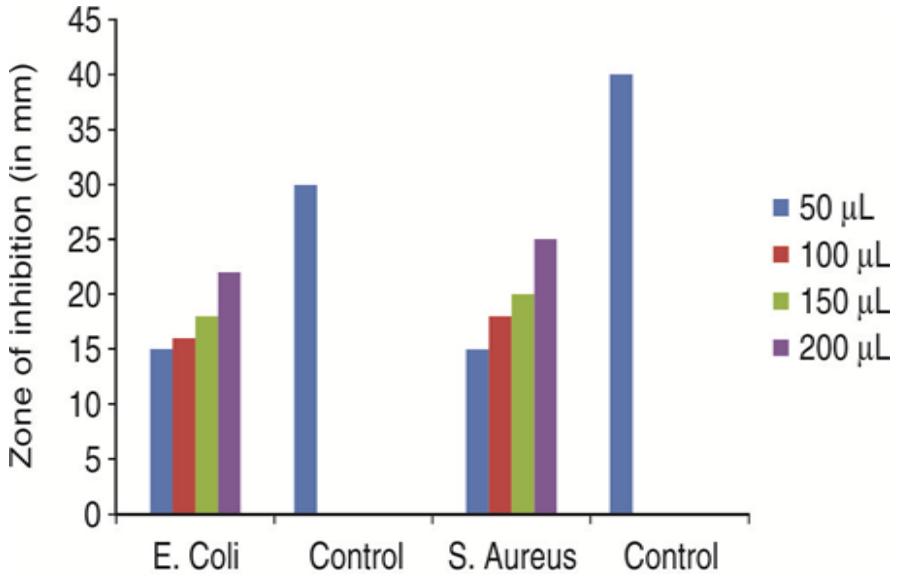

Figure 2. Anti-bacterial of ethanolic extract of M. oleifera.

negative strain (E. coli). Similar studies conducted by Bukar et al. (2010) and Nepolean et al. (2009) reported that ethanol leaf extracts were sensitive to $S$. aureus and $E$. coli at concentration of $200 \mathrm{mg} / \mathrm{ml}$. However, a contrary finding was reported by Arzai (2008) where no antimicrobial activity was observed at $125 \mathrm{mg} / \mathrm{ml}$ concentration on S. aureus but activity was obtained at higher concentration of $250 \mathrm{mg} / \mathrm{ml}$. Findings by Maroyi (2006) also found that leaf extract has antibacterial activity against $S$. aureus. The antibacterial properties of the leaf and seed of M. oleifera as shown in the present study was in conformity with earlier findings by Anwar et al. (2007); Akhtar et al. (2007) and Foidl et al. (2001) who reported antibacterial properties of seed and leaves extracts of M. oleifera. The antimicrobial activity of $M$. oleifera is due to the presence of a significant phytochemical of a short polypeptide called 4 (á-Lrhamnosyloxy) benzyl-isothiocyanate (Eilert et al., 1981; Guevara et al., 1999). This peptide act directly on bacteria and result in growth inhibition by disrupting cell membrane synthesis or synthesis of essential enzymes (Silvestre et al., 2000). Flavonoids and tannins have been reported to possess antimicrobial activity, the antimicrobial activity of flavonoids is due to their ability to complex with extracellular and soluble protein and to complex with bacterial cell wall while that of tannins may be related to their ability to inactivate microbial adhesions, enzymes and cell envelope proteins.

\section{Conclusion}

The ethanolic leaf extract of M. oleifera used in this experiment showed significant antibacterial activity against test pathogens, this thus supports the fact that $M$. oleifera contain contains active phytochemicals with wide-spectrum antibacterial activity, capable of inhibiting the growth of gram-positive and negative bacteria. The antibacterial activity of ethanolic leaf extract of M. oleifera could be due to the better solubility of its components in organic solvent, which indicates that the active components responsible for the bactericidal activity are more soluble in organic solvents. Detailed study is needed to investigate the active compounds present in these plant parts having antibacterial activity that may help us to design more effective chemotherapeutic agent to heal bacterial infections. 
Open Access: This is an open access article distributed under the terms of the Creative Commons Attribution 4.0 License, which permits unrestricted use, distribution, and reproduction in any medium, provided the original author(s) if the sources are credited.

\section{REFERENCES}

Akhtar, M., Hasany, S.M., Bhanger, M.I. and Iqbal, S. (2007). Sorption potential of Moringa oleifera pods for the removal of organic pollutants from aqueous solutions. Journal of Hazardous Materials, 141(3): 546-556, https:// doi.org/10.1016/j.jhazmat.2006.07.016

Anwar, F., Latif, S., Ashraf, M. and Gilani, A.H. (2007). Moringa oleifera: a food plant with multiple medicinal uses. Phytotherapy Research: An International Journal Devoted to Pharmacological and Toxicological Evaluation of Natural Product Derivatives, 21(1): 17-25, https://doi.org/10.1002/ ptr.2023

Arzai, A.H. (2008). Detection of ß-lactamase producing microorganisms and their susceptibility to selected antibiotics and medicinal plant extracts. $\mathrm{PhD}$ thesis submitted to the Department of Biological Sciences, Bayero University, Kano.

Barminas, J.T., Charles, M. and Emmanuel, D. (1998). Mineral composition of non-conventional leafy vegetables. Plant Foods for Human Nutrition, 53(1): 29-36, https:// doi.org/10.1023/A:1008084007189

Berkovich, L., Earon, G., Ron, I., Rimmon, A., Vexler, A. and Lev-Ari, S. (2013). Moringa oleifera aqueous leaf extract down-regulates nuclear factor-kappaB and increases cytotoxic effect of chemotherapy in pancreatic cancer cells. BMC Complementary and Alternative Medicine, 13(1): 212, https://doi.org/10.1186/1472-6882-13-212

Bukar, A., Uba, A. and Oyeyi, T. (2010). Antimicrobial profile of Moringa oleifera Lam. extracts against some food-borne microorganisms. Bayero Journal of Pure and Applied Sciences, 3(1), http://dx.doi.org/10.4314/bajopas.v3i1.58706

Cáceres, A., Saravia, A., Rizzo, S., Zabala, L., De Leon, E. and Nave, F. (1992). Pharmacologie properties of Moringa oleifera. 2: Screening for antispasmodic, antiinflammatory and diuretic activity. Journal of Ethnopharmacology, 36(3): 233237, https://doi.org/10.1016/0378-8741(92)90049-W

Daba, M. (2016). Miracle tree: A review on multi-purposes of Moringa oleifera and its implication for climate change mitigation. Journal of Earth Science \& Climatic Change, 7(4), https://doi.org/10.4172/2157-7617.1000366

Eilert, U., Wolters, B. and Nahrstedt, A. (1981). The antibiotic principle of seeds of Moringa oleifera and Moringa stenopetala. Planta Medica, 42(05): 55-61.

Ghasi, S., Nwobodo, E. and Ofili, J.O. (2000). Hypocholesterolemic effects of crude extract of leaf of Moringa oleifera Lam in high-fat diet fed Wistar rats. Journal of Ethnopharmacology, 69(1): 21-25, https://doi.org/10.1016/S0378-8741 (99)00106-3
Guevara, A.P., Vargas, C., Sakurai, H., Fujiwara, Y., Hashimoto, K., Maoka, T. and Nishino, H. (1999). An antitumor promoter from Moringa oleifera Lam. Mutation Research/Genetic Toxicology and Environmental Mutagenesis, 440(2): 181-188, https://doi.org/10.1016/S1383-5718(99)00025-X

Hindler A. J. and Jorgensen J. H. B. (1995). Procedures in antimicrobial susceptibility testing. In: Mahon, C.R., Manuselis, Jr. G. Textbook of diagnostic microbiology. Philadelphia: W.B. Saunders, pp. 63-64.

Jung, I.L. (2014). Soluble extract from Moringa oleifera leaves with a new anti-cancer activity, Plos One, 9:1-10, https:// doi.org/10.1371/journal.pone.0095492

Kasolo, J.N., Bimenya, G.S., Ojok, L., Ochieng, J. and Ogwal-Okeng, J.W. (2010). Phytochemicals and uses of Moringa oleifera leaves in Ugandan rural communities. Journal of Medicinal Plants Research, 4(9): 753-757, https:// doi.org/10.5897/JMPR10.492

Leelawat, S. and Leelawat, K. (2014). Moringa oleifera extracts induce cholangiocarcinoma cell apoptosis by induction of reactive oxygen species production. International Journal of Pharmacognosy and Phytochemical Research, 6: 183-189.

Liou, G.Y. and Storz, P. (2010). Reactive oxygen species in cancer. Free Radical Research, 44(5): 479-496, https:// doi.org/10.3109/10715761003667554

Maroyi, A. (2006). Preliminary checklist of introduced and naturalized plants in Zimbabwe. Kirkia, pp. 177-247, https://www.jstor.org/stable/23502330

Mbikay, M. (2012). Therapeutic potential of Moringa oleifera leaves in chronic hyperglycemia and dyslipidemia: a review. Frontiers in Pharmacology, 3: 24, https://doi.org/10.3389/ fphar.2012.00024

Mehta, K., Balaraman, R., Amin, A.H., Bafna, P.A. and Gulati, O.D. (2003). Effect of fruits of Moringa oleifera on the lipid profile of normal and hypercholesterolaemic rabbits. Journal of Ethnopharmacology, 86(2-3): 191-195, https:// doi.org/10.1016/S0378-8741(03)00075-8

Nepolean, P., Anitha, J. and Emilin, R.R. (2009). Isolation, analysis and identification of phytochemicals of antimicrobial activity of Moringa oleifera Lam. Current Biotica, 3(1): 33-37.

Nikkon, F., Saud, Z.A., Rehman, M.H. and Haque, M.E. (2003). In vitro antimicrobial activity of the compound isolated from chloroform extract of Moringa oleifera Lam. Pakistan Journal of Biological Sciences, 22: 1888-1890.

Pal, S.K., Mukherjee, P.K. and Saha, B.P. (1995). Studies on the antiulcer activity of Moringa oleifera leaf extract on gastric ulcer models in rats. Phytotherapy Research, 9(6): 463-465. https://doi.org/10.1002/ptr.2650090618

Patel Rameshwar, K., Manish, M.P., Nilesh, R.K., Kirit, R.V. and Patel, R.K. (2010). In vitro hepatoprotective activity of Moringa oleifera Lam. Leave on isolated Rat hepatocytes. International Journal of Pharmaceutical Sciences, 2(1): 457-463.

Rockwood, J.L., Anderson, B.G. and Casamatta, D.A. (2013). Potential uses of Moringa oleifera and an examination of 
antibiotic efficacy conferred by $M$. oleifera seed and leaf extracts using crude extraction techniques available to underserved indigenous populations. International Journal of Phytotherapy Research, 3: 61-71.

Ruckmani, K., Kavimani, S., An, R. and Jaykar, B. (1998). Effect of Moringa oleifera Lam on paracetamol-induced hepatotoxicity. Indian Journal of Pharmaceutical Sciences, 60(1): 33.

Silvestre, M.A., Escribá, M.J., Saeed, A.M. and García-Ximénez, F.
(2000). Preliminary studies on adult somatic nuclear transfer in pigs: effects of electrofusion pulses and postfusion cytochalasin $B$ treatments. In: $16^{\text {th }}$ Meeting of the AETE Santander (España), pp. 210.

Vinoth, B., Manivasagaperumal, R. and Balamurugan, S. (2012). Phytochemical analysis and antibacterial activity of Moringa oleifera Lam. International Journal of Research in Biological Sciences, 2(3): 98-102. 